\title{
Thermodynamic properties of moisture desorption isotherms of ryegrass (Lolium multiflorum L.) seeds
}

\section{Propriedades termodinâmicas das isotermas de dessorção de água de sementes azevém (Lolium multiflorum L.)}

\author{
Juliana Soares Zeymer ${ }^{* *}$ (D) Paulo Cesar Corrêa ${ }^{1}$ (D), Gabriel Henrique Horta de Oliveira² (D), \\ Marcos Eduardo Viana de Araujo ${ }^{1}$ (D), Diana Soares Magalhães ${ }^{1}$
}

${ }^{1}$ Universidade Federal de Viçosa/UFV, Departamento de Engenharia Agrícola e Ambiental, Viçosa, MG, Brasil

${ }^{2}$ Instituto Federal do Sudeste de Minas Gerais, Manhuaçu, MG, Brasil

${ }^{*}$ Corresponding author: jujuszeymer@gmail.com

Received in November 14, 2019 and approved in February 19, 2020

\begin{abstract}
Studies about the thermodynamic properties of ryegrass seeds are necessary to improve post-harvest processes, relating the factors that affect product quality with the interaction between water and its chemical components. Given the importance of recognizing and understanding the intrinsic behavior of water in ryegrass seeds and providing data for the improvement of industrial drying equipment, this work aimed to calculate and evaluate the thermodynamic properties of moisture desorption of ryegrass seeds as a function of the equilibrium moisture content. Ryegrass seeds with initial moisture content of 10.4 (\% d.b.) was used. The equilibrium moisture content of seeds was determined by static-gravimetric method at different temperatures $\left(10,20,30,40\right.$, and $50^{\circ} \mathrm{C}$ ) and water activity values (between 0.10 and 0.90 ), in three repetitions. The Chung Pfost model presented the best fit to the experimental data. It was observed that the integral isosteric desorption heat increased as the equilibrium moisture content decreased, ranged from 2499.95 to $4241.96 \mathrm{~kJ} \mathrm{~kg}^{-1}$ in the moisture content range 2.80 to 22.10 (\% d.b.). Differential entropy also increased with decreasing equilibrium moisture content, as did Gibbs free energy, being positive for all temperature studied, indicating that ryegrass seeds desorption is a non-spontaneous process. The enthalpy-entropy compensation theory was satisfactorily applied to the sorption phenomenon, being controlled by enthalpy.
\end{abstract}

Index terms: Gibbs free energy; entropy; enthalpy; water activity; Chung Pfost.

\begin{abstract}
RESUMO
Estudos sobre as propriedades termodinâmicas de sementes de azevém são necessários para melhorar os processos pós-colheita, relacionando os fatores que afetam a qualidade do produto com a interação entre a água e seus componentes químicos. Dada a importância de reconhecer e entender o comportamento intrínseco da água em sementes de azevém e fornecer dados para a melhoria de equipamentos de secagem industriais, este trabalho teve como objetivo calcular e avaliar as propriedades termodinâmicas da dessorção de água de sementes de azevém em função do teor de água de equilíbrio. Utilizou-se sementes de azevém com teor de água inicial de 10,4 (\% b.s.). O teor de água de equilíbrio das sementes foi determinado pelo método estático-gravimétrico, para diferentes valores de temperatura $\left(10,20,30,40\right.$ e $50^{\circ} \mathrm{C}$ ) e atividade de água (entre 0,10 e 0,90), em três repetições. O modelo Chung Pfost foi o que apresentou o melhor ajuste aos dados experimentais. Observou-se que o calor isostérico integral de dessorção aumentou à medida que o teor de água de equilíbrio diminuiu, variando de 2499,95 a 4241,96 kJ kg-1 na faixa de teor de água entre 2,80 a 22,10 (\% b.s.). A entropia diferencial também aumentou com a diminuição do teor de água em equilíbrio, assim como a energia livre de Gibbs, sendo positiva para todas as temperaturas estudadas, indicando que a dessorção de sementes de azevém é um processo não espontâneo. A teoria da compensação entalpia-entropia foi satisfatoriamente aplicada ao fenômeno de sorção de água, sendo controlado pela entalpia.
\end{abstract}

Termos para indexação: Energia livre de Gibbs; entropia; entalpia; atividade de água; Chung Pfost.

\section{INTRODUCTION}

The ryegrass (Lolium multiflorum L.) is a species of the Poacea family, widespread in southern Brazil. The spread of this crop is primarily due to its ability to adapt to different soil and climate conditions, as well as its ease of management (Pellegrini et al., 2010). However, for the crop to demonstrate its potentialities, the importance of using good quality seeds is highlighted (Nobre et al., 2014; Savage; Bassel, 2016). Thus, studies on the thermodynamic properties of ryegrass seeds are necessary to improve post- 
harvest processes, relating the factors that affect product quality with the interaction between water and its chemical components.

Thermodynamic properties can be calculated by sorption isotherms (Noshad et al., 2012; Hassini et al., 2015), allowing a greater understanding of the properties of water molecules and assisting in the calculation of energy in relation to heat transfer and heat transfer mass of biological systems (Goneli et al., 2016). In addition, determining these properties is critical to predicting the drying threshold in order to obtain a product that can be stored for long periods, consuming a minimum amount of energy to reduce moisture content at safe storage levels (Resende et al., 2017).

The knowledge of thermodynamic parameters provides essential information for studies on water surface properties of food (Hassini et al., 2015), such as specific surface area, pore radius and crystallinity (Spada et al., 2013). Enthalpy variations provide the energy variation related to the interaction between water molecules and the solvent. Entropy is related to the binding or repulsion of forces in the system (McMinn; Al-Muhtaseb; Magee, 2005). The application of the Clausius-Clapeyron equation to sorption isotherms is used to calculate the isosteric heat of sorption of food products (Madamba; Driscoll; Buckle, 1996; Gabas; Telis-Romeor; Menegalli, 1999). Enthalpyentropy compensation is a promising theory that has been widely considered in investigations of physical and chemical phenomena, such as desorption reactions under different conditions (Madamba; Driscoll; Buckle, 1996).

Recently, thermodynamic parameters such as enthalpy, entropy, Gibbs free energy and isosteric heat, among others, have been investigated for different types of grains and seeds, such as Opuntia ficus indica seeds (Hassini et al., 2015), Salvia hispanica L. seeds (Velázquez-Gutiérrez et al., 2015), Piper nigrum L. seeds (Yogendrarajah et al., 2015), Tamarindus indica L. seeds (Alpizar-Reys et al., 2017), Beta vulgaris L. seeds (Oliveira et al., 2017), Phaseolus vulgaris L. grains (Miano; Sabadoti; Augusto, 2018), Lactuca sativa L. seeds (Zeymer et al., 2018a), Oryza sativa L. grains (Zeymer et al., 2018b), Helianthus annuus L. seeds (Campos et al., 2019), Triticum vulgare L. grains (Mattioda; Jorge; Jorge, 2019). However, studies involving the thermodynamic properties of moisture sorption of ryegrass seeds have not yet been performed.

Given the importance of recognizing and understanding the intrinsic behavior of water in ryegrass seeds and providing data for the improvement of industrial drying equipment, this work aimed to calculate and evaluate the thermodynamic properties of moisture desorption of ryegrass seeds as a function of the equilibrium moisture content.

\section{MATERIAL AND METHODS}

Lolium multiflorum L. seeds with initial moisture content of $10.4 \%$ (d.b.) were purchased from the local market of Viçosa-MG and transported to the Laboratory of Physical Properties and Quality Assessment of Agricultural Products at the Federal University of Viçosa, Viçosa, MG. Then, the seeds were packed in low density polyethylene bags and stored in a B.O.D. (model $347 \mathrm{CD} /$ Fanem brand) at $5{ }^{\circ} \mathrm{C}$ until the beginning of the experiment.

The static-gravimetric method was used to obtain the equilibrium moisture content of ryegrass seeds by desorption process (Brasil, 2009), under different temperature conditions $\left(10,20,30,40\right.$ and $\left.50 \pm 1{ }^{\circ} \mathrm{C}\right)$ and water activity (between 0.10 and 0.90 ) until the product reaches the equilibrium moisture content with the specified air conditions. These conditions were adopted due to the large climatic amplitude found in the ryegrass seeds producing regions; in addition, the storage of this product occurs at different seasons of the year and therefore has a wide range of psychometric air conditions. The temperatures used were controlled by a B.O.D. and water activity was provided by saturated saline solutions. Each sample consisted of $30 \mathrm{~g}$ of seeds in three repetitions.

During the process, the samples were periodically weighed on a digital analytical balance (model AY220/ Mars brand) and the hygroscopic equilibrium was reached when the mass variation was less than $0.01 \mathrm{~g}$ during three consecutive weighings. Then, the moisture content of the product was determined by the gravimetric method using a forced circulation oven at $105 \pm 1{ }^{\circ} \mathrm{C}$ for 24 hours in triplicate, according to Brasil (2009). The experimental design was completely randomized with five temperature levels $\left(10,20,30,40\right.$ and $\left.50^{\circ} \mathrm{C}\right)$, eight water activity levels $(0.1,0.3,0.4,0.5,0.6,0.7,0.8,0.9)$ and three repetitions. For the ryegrass seeds equilibrium moisture content experimental data, 10 mathematical models frequently used to predict hygroscopicity of agricultural products were adjusted: Copace, Sigma-Copace, Henderson, Modified Henderson, Modified Halsey, Chung Pfost, Oswin Modified, Smith, Modified GAB and Harkins. This study aims to identify the thermodynamic properties of moisture sorption in ryegrass seeds; thus, it will not present data regarding the analysis of the above mentioned models.

The model chosen to determine the thermodynamic properties of ryegrass seeds was the Chung Pfost (Chung; 
Pfost, 1967), as it showed the best fit to the experimental data, with a determination coefficient of $99.34 \%$; relative average error of $5.67 \%$; standard deviation from the estimate of 0.66 ; and random distribution of waste. Through this model, the water activity values were obtained through Equation 1:

$X_{e}=31.98376^{* *}-5.90103^{* *} \ln \left[-\left(T+22.81437^{* *}\right) \ln a_{w}\right]$

** Significant at $5 \%$ probability by " $\mathrm{t}$ " test.

Where:

$\mathrm{X}_{\mathrm{e}}$ - equilibrium moisture content (\%, d.b.);

$\mathrm{a}_{\mathrm{w}}$ - water activity (decimal);

$\mathrm{T}$ - temperature $\left({ }^{\circ} \mathrm{C}\right)$.

The thermodynamic properties entropy $(\Delta \mathrm{S})$, enthalpy $(\Delta H)$, Gibbs free energy $(\Delta G)$ and enthalpyentropy ratio were obtained according to the methodology previously described by Corrêa, Oliveira and Santos (2012). The equations for calculating these properties are presented in Equations 2, 3, 4, 5 and 6.

$\ln a_{w}= \pm \frac{\Delta H_{s t}}{R T}-\frac{\Delta S}{R}$

$\Delta H=\Delta H_{s t}-\Delta H_{v a p}$

$\Delta G= \pm R T \ln a_{w}$

$T_{B}=\hat{T}_{B} \pm t_{m-2 . \alpha / 2} \sqrt{V_{a r}\left(T_{B}\right)}$

$T_{h m}=\frac{n_{t}}{\sum_{i=1}^{n_{t}}\left(\frac{1}{T_{i}}\right)}$

Where:

$\mathrm{a}_{\mathrm{w}}$ - water activity (decimal);

$\Delta \mathrm{H}$ - isosteric heat of sorption or enthalpy $\left(\mathrm{kJ} \mathrm{kg}^{-1}\right)$;

$\mathrm{R}$ - universal gas constant, $0.462\left(\mathrm{~kJ} \mathrm{~kg}^{-1} \mathrm{~K}^{-1}\right)$;

$\Delta \mathrm{H}_{\text {vap }}$ - latent heat of pure water vaporization $\left(\mathrm{kJ} \mathrm{kg}^{-1}\right)$;

$\Delta \mathrm{H}_{\text {st }}^{\text {vap }}$ - integral isosteric heat of sorption $\left(\mathrm{kJ} \mathrm{kg}^{-1}\right)$;

$\Delta \mathrm{S}^{\text {st }}$ - differential sorption entropy $\left(\mathrm{kJ} \mathrm{kg}^{-1} \mathrm{~K}^{-1}\right)$;

$\Delta \mathrm{G}$ - Gibbs free energy $\left(\mathrm{kJ} \mathrm{kg}^{-1} \mathrm{~mol}^{-1}\right)$;

$\mathrm{T}_{\mathrm{B}}$ - isokinetic temperature $(\mathrm{K})$;

$\mathrm{m}$ - number of enthalpy and entropy data pairs;

$\mathrm{T}_{\mathrm{hm}}$ - average harmonic temperature $(\mathrm{K})$; e.

$n_{t}-$ number of temperatures used.

\section{RESULTS AND DISCUSSION}

Table 1 reports the water activity values predicted by Equation 1 as a function of temperature and equilibrium moisture content of ryegrass seeds.

For the same temperature, with increasing equilibrium moisture content, there is an increase in water activity. Previous research with different agricultural products also reported this behavior (Oliveira et al., 2011; Costa et al., 2015; Zeymer et al., 2018b; Campos et al., 2019). Water activity reports the amount of water molecules available for different reactions in the product, as well as the development of microorganisms; therefore, by increasing the equilibrium moisture content, a greater amount of moisture is available for these reactions, resulting in an increase in water activity $\left(\mathrm{a}_{\mathrm{w}}\right)$.

Figure 1 shows the integral isosteric desorption heat $\left(\mathrm{Q}_{\mathrm{st}}\right)$ values for ryegrass seeds as a function of equilibrium moisture content. (\% d.b.).

It is observed that reducing the equilibrium moisture content increases the energy required to evaporate the water bound to the biological structure of the product, represented by the values of the integral isosteric desorption heat (Figure 1), as observed for several products (Oliveira et al., 2011; Costa et al., 2015; Teixeira; Andrade; Devilla, 2018; Granella et al., 2019). This fact is related to the increase of the water retention capacity of the product in the lower values of equilibrium moisture content, due to the increase of the concentration of fats, proteins and salts of sodium chloride (Hubinger et al., 2009). According to Hubinger et al. (2009), the monomolecular layer is more strongly linked to the polar groups of these substances, due to the increased hydrogen bonds of water molecules that progressively form orderly and rigid structures, requiring more energy to break them to release a water molecule in the form of steam. Finally, at higher water activity values, fewer sites are available for the bonds between molecules, implying a need for movement of water molecules (Goneli et al., 2013; Oliveira et al., 2014; Resende et al., 2017).

The integral isosteric desorption heat values for ryegrass seeds in the equilibrium moisture content range from 2.8 to 22.1 (\% d.b.) ranged from 4241.96 to 2499.95 $\mathrm{kJ} \mathrm{kg}^{-1}$. Granella et al. (2019) found desorption integral isosteric heat values for Triticum vulgare L. seeds, with equilibrium moisture content of 9.42 and 17.92 (\% d.b.), between 4280.60 to $2602.85 \mathrm{~kJ} \mathrm{~kg}^{-1}$. The isosteric heat required for Guizotia abyssinica (L. f.) Cass. grain water removal for the equilibrium moisture content of 2.4 to 12.2 (\% d.b.) ranged from 3081.48 to $2539.62 \mathrm{~kJ} \mathrm{~kg}^{-1}$ (Siqueira 
et al., 2018). For Phaseolus vulgaris L. seeds, Cavalcanti, Rosa and Duarte (2018) reported values from 55.75 to $1184.87 \mathrm{~kJ} \mathrm{~kg}^{-1}$ for the equilibrium moisture content range between 5.0 and 30.0 (\% d.b.). These variations found between Qst values can be explained by the different chemical composition of the products, as well as by possible errors in obtaining the water activity values for each equilibrium moisture content, since the values were obtained from mathematical models (Ferreira; Pena, 2003).

It is observed that differential entropy is directly related to the ryegrass seeds equilibrium moisture content, where with the increase in the equilibrium moisture content, there is a decrease in the differential entropy $(\Delta S)$ (Figure 2). The results demonstrate that differential entropy behaves similarly to integral isosteric desorption heat with equilibrium moisture content. This behavior is expected, since entropy generation is controlled by heat transfer between the two properties, and its magnitude is always proportional to the heat transferred at a given temperature (Oliveira et al., 2017).

Differential entropy values of ryegrass seeds ranged from 0.03 to $4.45 \mathrm{~kJ} \mathrm{~kg}^{-1} \mathrm{~K}^{-1}$. Goneli et al. (2010), studying the thermodynamic properties of Abelmoschus esculentus L. seeds, verified the same behavior of the present work ( 0.10 to $10.84 \mathrm{~kJ} \mathrm{~kg}^{-1} \mathrm{~K}^{-1}$ ), as well as Zeymer et al. (2018a) working with Lactuca sativa $\mathrm{L}$. seeds $(0.14$ to $4.15 \mathrm{~kJ}$ $\mathrm{kg}^{-1} \mathrm{~K}^{-1}$ ). This behavior is related to the mobility of water molecules during the desorption process, where at higher water activity values, there are fewer sites available for the bonds between the molecules, resulting in less movement of water molecules (Goneli et al., 2010).

Figure 3 reports Gibbs free energy $(\Delta \mathrm{G})$ values as a function of equilibrium moisture content and temperature.

It was noted that Gibbs free energy increased with decreasing moisture content, being positive for all

Table 1: Water activity values (decimal) estimated by Chung Pfost model as a function of temperature $\left({ }^{\circ} \mathrm{C}\right.$ ) and equilibrium moisture content (\%, d.b.) of ryegrass seeds.

\begin{tabular}{cccccc}
\hline $\mathrm{X}_{\mathrm{e}}$ (\%) $\left.\mathrm{d} . \mathrm{f}\right)$ & \multicolumn{5}{c}{ Temperature $\left({ }^{\circ} \mathrm{C}\right)$} \\
\cline { 2 - 5 } 2.80 & 0.0035 & 0.0375 & 0.0699 & 0.1067 & 0.1451 \\
3.20 & 0.0138 & 0.0465 & 0.0832 & 0.1236 & 0.1647 \\
4.20 & 0.0341 & 0.0751 & 0.1226 & 0.1712 & 0.2182 \\
5.50 & 0.0665 & 0.1253 & 0.1856 & 0.2427 & 0.2948 \\
6.00 & 0.0829 & 0.1483 & 0.2128 & 0.2723 & 0.3255 \\
6.90 & 0.1179 & 0.1942 & 0.2649 & 0.3273 & 0.3816 \\
8.00 & 0.1696 & 0.2567 & 0.3321 & 0.3958 & 0.4495 \\
8.40 & 0.1905 & 0.2806 & 0.3569 & 0.4205 & 0.4737 \\
9.50 & 0.2526 & 0.3483 & 0.4253 & 0.4873 & 0.5379 \\
10.00 & 0.2824 & 0.3795 & 0.4559 & 0.5166 & 0.5656 \\
10.60 & 0.3191 & 0.4167 & 0.4918 & 0.5507 & 0.5977 \\
12.00 & 0.4062 & 0.5013 & 0.5714 & 0.6246 & 0.6663 \\
12.20 & 0.4186 & 0.5130 & 0.5821 & 0.6345 & 0.6754 \\
13.00 & 0.4675 & 0.5583 & 0.6235 & 0.6722 & 0.7098 \\
14.30 & 0.5433 & 0.6265 & 0.6845 & 0.7271 & 0.7596 \\
15.50 & 0.6078 & 0.6828 & 0.7340 & 0.7710 & 0.7990 \\
15.70 & 0.6180 & 0.6915 & 0.7416 & 0.7777 & 0.8050 \\
17.50 & 0.7014 & 0.7620 & 0.8022 & 0.8308 & 0.8523 \\
20.20 & 0.7989 & 0.8419 & 0.8698 & 0.8893 & 0.9038 \\
22.10 & 0.8499 & 0.8828 & 0.9039 & 0.9185 & 0.9293 \\
\hline
\end{tabular}

Where: $\mathrm{X}_{\mathrm{e}}$ - equilibrium moisture content (\% d.b.). 


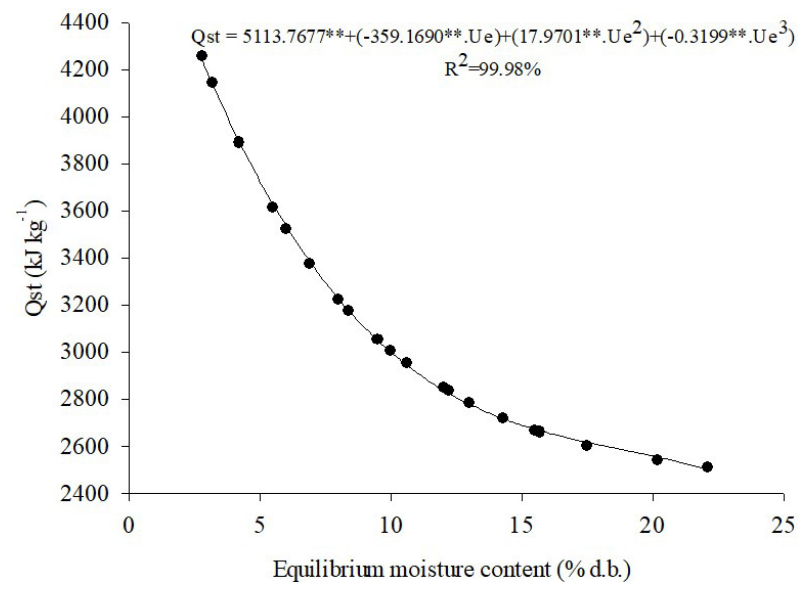

Figure 1: Observed and estimated values of the integral isosteric desorption heat (Qst) of ryegrass seeds as a function of equilibrium moisture content. ** significant at $1 \%$ probability by the " $\mathrm{t}$ " test.

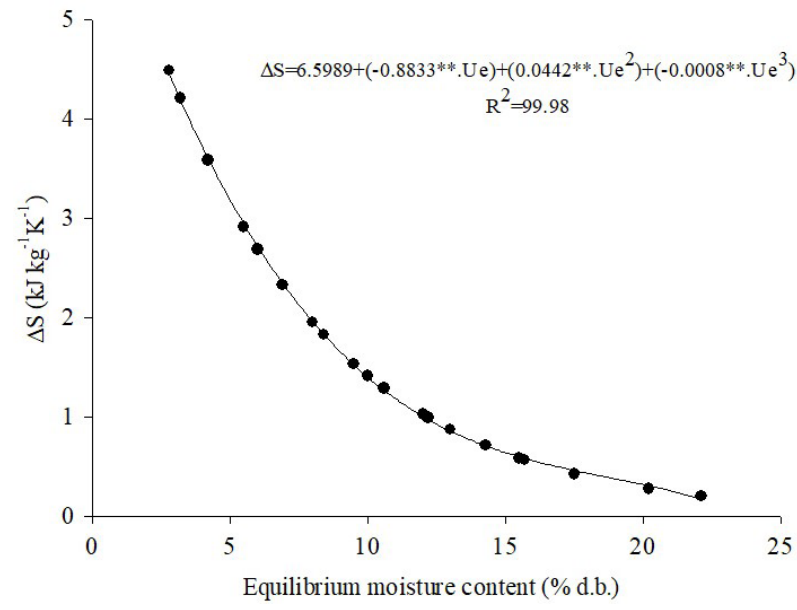

Figure 2: Observed and estimated values of differential ryegrass desorption entropy as a function of equilibrium moisture content.

** significant at $1 \%$ probability by the " $\mathrm{t}$ " test.

temperatures studied, tending to stabilize at higher levels of equilibrium moisture content (Figure 3). This trend was also observed by Oliveira et al. (2010) and by Campos et al. (2019), studying Zea mays L. and Helianthus annuus L. seeds, respectively.

It is also noted that the Gibbs free energy decreases with increasing temperature. This is due to the higher level of excitation of molecules present in seeds, accelerating gas exchange, making the process faster (Zeymer et al., 2018a). The influence of temperature decreases with increasing equilibrium moisture content, since at high values of equilibrium moisture content sorption sites are available (Goneli et al., 2013).

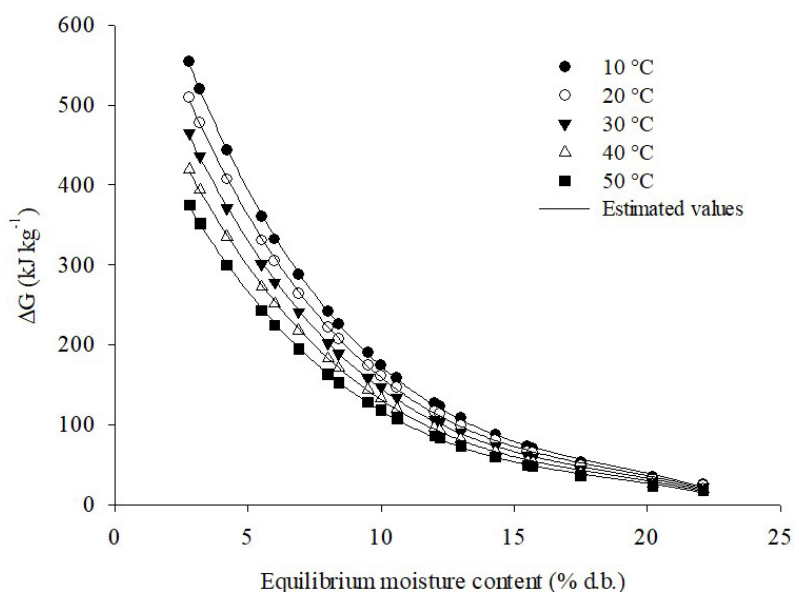

Figure 3: Gibbs free energy as a function of ryegrass seeds equilibrium moisture content.

Nkolo Meze'e, Noah Ngamveng and Bardet (2008) report that Gibbs free energy is related to the work needed to make sorption sites available. Positive Gibbs free energy values are characteristic of an exogenous reaction, that is, one that needs an external agent supplying energy to the environment. These positive values were already expected, since desorption is a non-spontaneous process, which means that requires the insertion of external energy for the process to occur.

Table 2 shows the Gibbs free energy regression equations as a function of temperature.

It can be noticed that the coefficients of the equations show behavior as a function of temperature. In that way, linear regression analysis was performed, in which all parameters presented a coefficient of determination of 1.0 with temperature, thus reaching Equation 7. This equation is the general Gibbs free energy equation as a function of temperature in ${ }^{\circ} \mathrm{C}$ :

$$
\begin{aligned}
& \Delta G=(-6.5989 T+880.72)+\left[(0.8833 T-117.89) X_{e}\right]+ \\
& +\left[(-0.0442 T+5.8980) X_{e}^{2}\right]+\left[(0.0008 T-0.1050) X_{e}^{3}\right]
\end{aligned}
$$

Where:

$\Delta \mathrm{G}-$ Gibbs free energy $\left(\mathrm{kJ} \mathrm{kg}^{-1}\right)$;

$\mathrm{X}_{\mathrm{e}}-$ equilibrium moisture content (\%, d.b.);

$\mathrm{T}$ - temperature $\left({ }^{\circ} \mathrm{C}\right)$. 
Table 2: Regression equations adjusted to experimental values of Gibbs free energy $(\Delta G)$ of ryegrass seeds, at different temperatures $\left({ }^{\circ} \mathrm{C}\right)$, as a function of equilibrium moisture content $\left(\mathrm{X}_{\mathrm{e}}\right)$.

\begin{tabular}{ccc}
\hline Temperature $\left({ }^{\circ} \mathrm{C}\right)$ & Equation & $\mathrm{R}^{2}(\%)$ \\
\hline 10 & $\Delta \mathrm{G}=814.7277+\left(-109.0524 \mathrm{X}_{\mathrm{e}}\right)+\left(5.4560 \mathrm{X}_{\mathrm{e}}^{2}\right)+\left(-0.0971 \mathrm{X}_{\mathrm{e}}^{3}\right)$ & 99.98 \\
20 & $\Delta \mathrm{G}=748.7389+\left(-100.2194 \mathrm{X}_{\mathrm{e}}\right)+\left(5.0141 \mathrm{X}_{\mathrm{e}}^{2}\right)+\left(-0.0893 \mathrm{X}_{\mathrm{e}}^{3}\right)$ & 99.96 \\
30 & $\Delta \mathrm{G}=682.7500+\left(-91.3863 \mathrm{X}_{\mathrm{e}}\right)+\left(4.5721 \mathrm{X}_{\mathrm{e}}^{2}\right)+\left(-0.0814 \mathrm{X}_{\mathrm{e}}^{3}\right)$ & 99.98 \\
40 & $\Delta \mathrm{G}=616.7612+\left(-82.5533 \mathrm{X}_{\mathrm{e}}\right)+\left(4.1302 \mathrm{X}_{\mathrm{e}}^{2}\right)+\left(-0.0735 \mathrm{X}_{\mathrm{e}}{ }^{3}\right)$ & 99.99 \\
50 & $\Delta \mathrm{G}=550.7724+\left(-73.7203 \mathrm{X}_{\mathrm{e}}\right)+\left(3.6882 \mathrm{X}_{\mathrm{e}}^{2}\right)+\left(-0.0657 \mathrm{X}_{\mathrm{e}}^{3}\right)$ & 99.97 \\
\hline
\end{tabular}

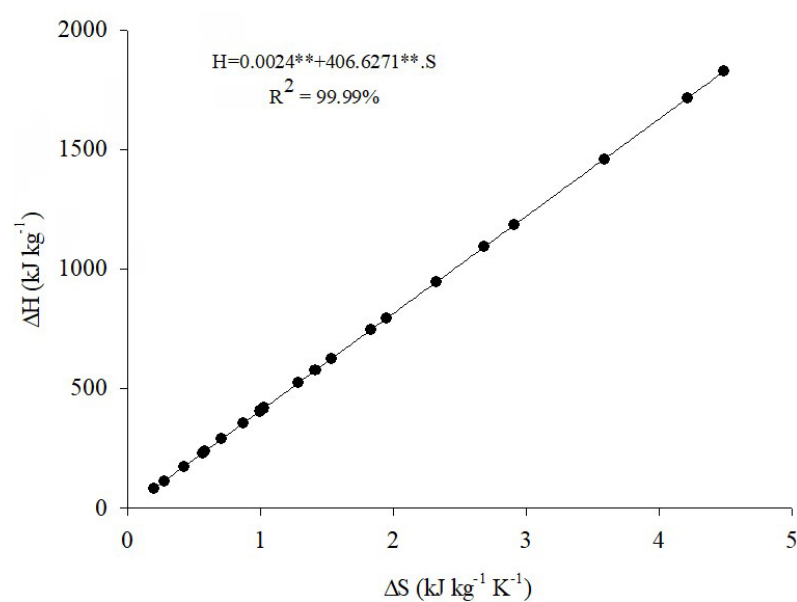

Figure 4: Linear relationship between enthalpy and entropy for moisture desorption of ryegrass seeds.

** significant at $1 \%$ probability by the " $\mathrm{t}$ " test.

The relationship between enthalpy $(\mathrm{H})$ and entropy (S) of the desorption process for ryegrass seeds was evaluated according to a linear regression, presenting a high coefficient of determination (99.99\%) (Figure 4).

With the linearity between the differential enthalpy relation and the differential sorption entropy, the isokinetic theory, or enthalpy-entropy compensation theory, can be considered valid for the moisture desorption phenomenon. Other studies have also reported this same behavior (Oliveira et al., 2010; Goneli et al. 2010; Hassini et al., 2015; Zeymer et al., 2018a; Campos et al., 2019).

To test the validity of the enthalpy-entropy compensation theory, the isokinetic temperature was compared with the harmonic mean $\left(\mathrm{T}_{\mathrm{hm}}\right)$ of the studied temperature range used to determine the desorption process in ryegrass seeds. In enthalpy-entropy linear compensation, it was found that if $\mathrm{T}_{\mathrm{B}}>\mathrm{T}_{\mathrm{hm}}$, the process is controlled by enthalpy, otherwise $\left(\mathrm{T}_{\mathrm{B}}>\mathrm{T}_{\mathrm{hm}}\right)$, the process is controlled by entropy (Gabas; Telis-Romeor; Menegalli, 1999).
The isokinetic temperature was $405.87 \mathrm{~K}$, while the harmonic mean was $302.50 \mathrm{~K}$, being significantly different from the isokinetic temperature values, confirming the phenomenon of enthalpy-entropy compensation for the ryegrass seeds desorption process. The isokinetic temperature was higher than the harmonic average temperature, showing that the process is controlled by enthalpy. These results are in line with what has been observed by several researchers who have applied the isokinetic theory of sorption of different agricultural products (Oliveira et al., 2010; Goneli et al. 2010; Hassini et al., 2015; Zeymer et al., 2018a, Campos et al., 2019).

\section{CONCLUSIONS}

Integral isosteric desorption heat increased as the equilibrium moisture content decreased, indicating an increase in energy required to remove moisture from the product. The integral isosteric desorption heat values ranged from 2499.95 to $4241.96 \mathrm{~kJ} \mathrm{~kg}^{-1}$ under the desorption conditions of the present work. Differential entropy also increased with decreasing equilibrium moisture content, as did Gibbs free energy, which is always positive, indicating that ryegrass seeds desorption is a non-spontaneous process. Differential entropy values for ryegrass seeds ranged from $0.03 \mathrm{~kJ} \mathrm{~kg}^{-1} \mathrm{~K}^{-1}$ to $4.45 \mathrm{~kJ} \mathrm{~kg}^{-1} \mathrm{~K}^{-1}$ and Gibbs free energy values between 21.11 and $552.87 \mathrm{~kJ} \mathrm{~kg}^{-1}$. The enthalpyentropy compensation theory is valid for the ryegrass seeds desorption process and is controlled by enthalpy.

\section{REFERENCES}

ALPIZAR-REYES, E. et al. Thermodynamic sorption properties and glass transition temperature of tamarind seed mucilage (Tamarindus indica L.). Food and Bioproducts Processing, 101:166-176, 2017.

BRASIL, Ministério da Agricultura e Reforma Agrária. Secretaria Nacional de Defesa Agropecuária. Regras para análise de sementes, Brasília, 2009. 388p. 
CAMPOS, R. C. et al. Moisture sorption isotherms of sunflower seeds: Thermodynamic analysis. Ciência e Agrotecnologia, 43:e011619, 2019.

CAVALCANTI, A. S. R. R. M.; ROSA, M. E. R. C.; DUARTE, M. E. M. Propriedades termodinâmicas as sementes de feijão branco com base nas isotermas de equilíbrio higroscópico. Revista Brasileira de Produtos Agroindustriais, 20(3):239-246, 2018.

CHUNG, D. S.; PFOST, H. B. Adsorption and desorption of water vapors by cereal grains and their products Part II. Transactions of the ASAE, 10:549-551, 1967.

COSTA, L. M. et al. Isotermas e calor isostérico de sementes de Buchenavia capitata (Vahl) Eichler. Revista Ciência Agronômica, 46(3):516-523, 2015.

CORRÊA, P. C.; OLIVEIRA, G. H. H.; SANTOS, E. S. Thermodynamic properties of agricultural products processes. In: ARANA, I. (org.) Physical properties of foods: Novel measurement techniques and applications. Boca Raton: CRC Press, 2012. p.131-141.

FERREIRA, C. D.; PENA, R. S. Comportamento higroscópico da farinha de pupunha (Bactris gasipaes). Ciência e Tecnologia de Alimentos, 23(2):251-255, 2003.

GABAS, A. L.; TELIS-ROMEOR, J.; MENEGALLI, F. C. Thermodynamic models of water sorption by grape skin and pulp. Drying Technology, 17(4-5):961-974, 1999.

GONELI, A. L. D. et al. Water desorption and thermodynamic properties of okra seeds. Transaction of the ASAE, 53(1):191-197, 2010.

GONELI, A. L. D. et al. Water sorption properties of coffee fruits, pulped and green coffee. Food Science and Technology, 50(2):386-391, 2013.

GONELI, A. L. D. et al. Moisture sorption isotherms of castor beans. Part 2: Thermodynamic properties. Revista Brasileira de Engenharia Agrícola e Ambiental, 20(8):757-762, 2016.

GRANELLA, S. J. et al. Isotermas e calor isostérico de dessorção da água em sementes de trigo. Revista Engenharia na Agricultura, 27(4):304-312, 2019.

HASSINI, L. et al. Desorption isotherms and thermodynamic properties of prickly pear seeds. Industrial Crops and Products, 67:457-465, 2015.

HUBINGER, M. D. et al. Isotermas de dessorção de filé de bonito (Sarda sarda) desidratado osmoticamente e defumado. Revista Brasileira de Engenharia Agrícola e Ambiental, 13(3):305-311, 2009.
MADAMBA, P. S.; DRISCOLL, R. H.; BUCKLE, K. A. Enthalpyentropy compensation models for sorption and browning of garlic. Journal of Food Engineering, 28(2):109-119, 1996.

MATTIODA, F.; JORGE, L. M. M.; JORGE, R. M. M. Mathematical modeling of wheat hydration: Process an starch properties. Food Process Engineering, 42(1):e12936, 2019. Available in: <https://onlinelibrary.wiley.com/doi/full/10.1111/ jfpe.12936>. Access in: Oct. 18, 2019.

MCMinN, W. A. M.; AL-MUhtASEB, A. H.; MAGEE, T. R. A. Enthalpy-entropy compensation in sorption phenomena of starch materials. Journal of Food Engineering, 38: 505-510, 2005.

MIANO, A. C.; SABADOTI, V. D.; AUGUSTO, P. E. D. Enhancing the hydration process of common beans by ultrasound and high temperatures: Impact on cooking and thermodynamic properties. Journal of Food Engineering, 225:53-61, 2018.

NOSHAD, M. et al. Desorption isotherms and thermodynamic properties of fresh and osmoticultrasonic dehydrated quince. Journal of Food Processing Preservation, 37:112, 2012.

NOBRE, D. A. C. et al. Desempenho físico e fisiológico de sementes de mamona produzidas no norte de Minas Gerais. Revista Agrarian, 7(24):218-225, 2014.

NKOLO MEZE'E, Y. N.; NOAH NGAMVENG, J.; BARDET, S. Effect of enthalpy-entropy compensation during sorption of water vapour in tropical woods: The case of Bubinga (Guibourtia Tessmanii J. Léonard; G. Pellegriniana J.L.). Thermochimica Acta, 468(1-2): 1-5, 2008.

OLIVEIRA, D. E. C. et al. Propriedades termodinâmicas das sementes de pinhão-manso. Bioscience Journal, 30(1):147-157, 2014.

OLIVEIRA, G. H. H. et al. Desorption isotherms and thermodynamic properties of sweet corn cultivars (Zea mays L.). International Journal of Food Science and Technology, 45(3):546-554, 2010.

OLIVEIRA, G. H. H. et al. Evaluation of thermodynamic properties using GAB model to describe the desorption process of cocoa beans. International Journal of Food Science and Technology, 46(10):2077- 2084, 2011.

OLIVEIRA, G. H. H. et al. Application of GAB model for water desorption isotherms and thermodynamic analysis of sugar beet seeds. Food Process Engineering, 40(1):e12278, 2017. Available in: <https://onlinelibrary.wiley.com/doi/ full/10.1111/jfpe.12278>. Access in: Oct. 19, 2019. 
PELLEGRINI, L. G. et al. Produção e qualidade de azevémanual submetido a adubação nitrogenada sob pastejo por cordeiros. Revista Brasileira de Zootecnia, 39(9):18941904, 2010.

RESENDE, O. et al. Thermodynamic properties of baru fruits (Dipteryx alata Vogel). Engenharia Agrícola, 37(4):739-749, 2017.

SAVAGE, W. E. F.; BASSEL, G. W. Seed vigour and crop establishment: Extending performance beyond adaptation. Journal of Experimental Botany, 67(3):567-591, 2016.

SIQUEIRA, C. S. et al. Desorption isotherms and isosteric heat of niger grains (Guizotia abyssinica (L. f.) Cass.). Revista Agro@mbiente On-line, 12(2):124-133, 2018.

SPADA, J. C. et al. Water adsorption isotherms of microcapsules with hydrolyzed pinhão (Araucaria angustifólia seeds) starch as wall material. Journal of Food Engineering, 114(1): 64-69, 2013.
TEIXEIRA, L. P.; ANDRADE, E. T.; DEVILLA, I. A. Isosteric heat, entropy and Gibbs free energy of pumpkin seeds (Cucurbita moschata). Engenharia Agrícola, 38(1):97-102, 2018.

VELÁZQUEZ-GUTIÉRREZ, S. K. et al. Sorption isotherms, thermodynamic properties and glass transition temperature of mucilage extracted from chia seeds (Salvia hispânica L.). Carbohydrate Polymers, 121(5):411-419, 2015.

ZEYMER, J. S. et al. Thermodynamic properties of water desorption in lettuce seeds. Semina: Ciências Agrárias, 39(3):921-932, 2018a.

ZEYMER, J. S. et al. Thermodynamic properties of sorption of rice in the husk. Engenharia Agrícola, 38(3):369-375, $2018 b$.

YOGENDRARAJAH, P. et al. Moisture sorption isotherms and thermodynamic properties of whole black peppercorns (Piper nigrum L.). LWT-Food Science and Technology, 64(1):177-188, 2015. 